\title{
Evolution of Political Branding: Typologies, Diverse Settings and Future Research
}

\begin{abstract}
Political branding has developed into an established and vibrant sub-discipline of political marketing. Indeed, political branding research continues to push boundaries by critically applying consumer based branding theories, concepts and frameworks to the political environment. Recently, political branding scholars have segmented research into different categories such as corporate, candidate, leader, local-regional, internal or external in orientation. Despite this development, there continues to be limited research on alternative or different typologies of political brands. This study reaffirms political branding as a distinct area of research and discusses how political brands can be conceptualised and operationalised. Further, drawing on seven empirical and conceptual papers, which focus on different typologies of political brands from a range of international contexts including Canada, USA, Iceland, Indonesia and India, we reflect on the current political branding environment. We conclude that there are multiple relationships and numerous interconnected political brands, which represent an intricate environment or ecosystem. This study offers academics and political actors guidance on how to conceptualise political brands and provides a starting point to map out the ecosystems of political brands. Finally, this study provides explicit calls for further research in political branding.
\end{abstract}

DR CHRISTOPHER PICH

Nottingham Business School, Nottingham Trent University, United Kingdom

PROFESSOR BRUCE I NEWMAN

DePaul University, Chicago, Illinois, United States of America

All correspondence to Dr. Christopher Pich, Nottingham Trent University, Nottingham Business School, Marketing Division, $6^{\text {th }}$ Floor Newton Building, Burton Street Nottingham, NG1 4BU - 00441158483862 - Christopher.pich@ntu.ac.uk 


\section{Introduction}

This is the second special issue of a journal devoted entirely to research on the application of branding concepts, theories and frameworks to politics. Furthermore, this special issue builds on the first special issue devoted to political branding facilitated by Needham and Smith (2015). Indeed, Needham and Smith (2015) discussed advancements in the sub-discipline of political branding and presented explicit gaps for further research. Since then, progress has been made on political branding research focusing on the critical application of new concepts and frameworks, generating a deeper understanding of unexplored contexts and settings and positioning research from multiple perspectives (Billard 2018; Meyerrose 2017; Nai and Martinez 2019; Simons 2016). Despite the development of political branding, existing work continue to focus on the party leader or party political brands particularly in traditional political systems (Husted et al. 2018; Meyerrose 2017; Nielsen 2016). Given there are many potential typologies and non-traditional political brands, this grounds an area for future research. Therefore, this special issue investigates different typologies and alternative political brands with the support of new and under-developed theoretical lens from multiple perspectives and in contexts ranging from Canada, Iceland, India, Indonesia and the United States of America.

\section{Political Branding - A Distinct Area of Research}

Political branding has developed into a distinct area of research within the discipline of political marketing (Scammell 2015). Taking a step back, political branding can be simply defined as the critical application of traditional branding concepts, theories and frameworks to politics in order to provide differentiation from political competitors and identification between citizens and political entities (Harris and Lock 2010; Needham and Smith 2015). Further, the conceptualisation and investigation of political brands has developed

significantly over the last twenty year since the seminal work of Lock and Harris (1996). For example, there is a shared understanding that political parties [local-regional, national and international], pressure groups, movements, politicians, candidates and campaigns can be conceptualised as 'political brands' (Ahmed et al. 2015; Billard 2018; Meyerrose 2017; Nai and Martinez 2019; Simons 2016; Speed et al. 2015; Scammell 2015; Smith 2009). 
In addition, investigating how political brands are positioned by political actors and how they are understood in the minds of citizens continues to be a topical area of study across nationalinternational jurisdictions (Baines et al. 2014; Nielsen 2016). This insight allows political entities to develop long-term strategies and processes to develop and manage their brands (Pich et al. 2018). Recently, political branding research has started to segment into different categories such as corporate, candidate, leader, local-regional, internal or external in orientation. In fact, the case has been made that a political brand is an extension of research carried out in the for-profit and non-profit sectors, where the citizen/voter in the political marketplace can be viewed in a similar context as a consumer in the commercial marketplace (Newman and Newman 2018). Despite these developments, there continues to be limited research on alternative political brands, non-traditional political brands, new political brands and political brands in different settings and contexts. Further, there still seems to be very few pragmatic models-frameworks that can be used by political brands to assess their identity, image, reputation or position that will ultimately support the development of strategy and political brand management. This in turn is supported by broader explicit calls for further research on political branding (Billard 2018; Husted et al. 2018; Nai and Martinez 2019; Marland 2016; Nielsen et al. 2014).

\section{Political Branding - Conceptualisations and Operationalisation}

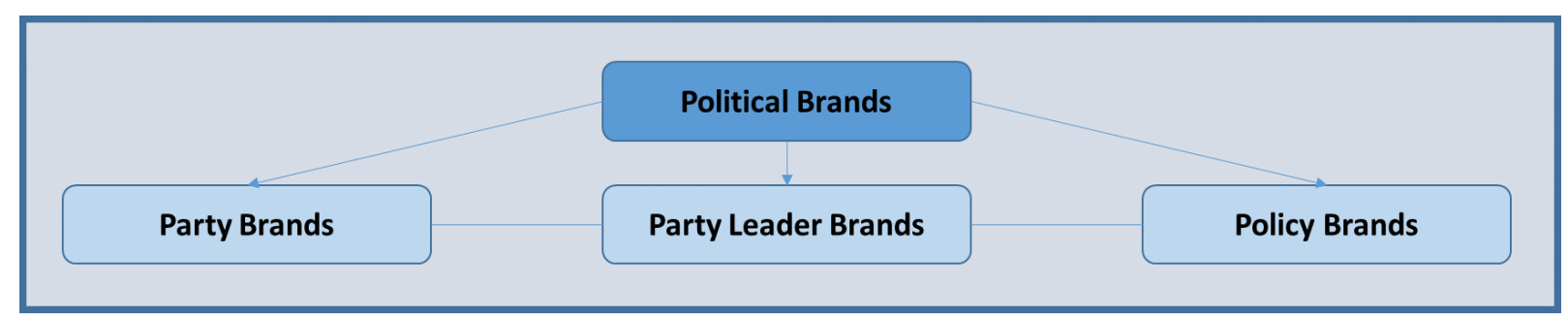

(Figure 1: The Political Brand Trinity)

Political brands are multifaceted and often complex entities designed to differentiate from competition (Lock and Harris, 1996; Phipps et al., 2010; Pich et al. 2018). Further, political brands are often difficult to operationalise. Nevertheless, political brands can be considered a trinity of elements including the party, leader and policy (Butler et al., 2011; Davies and Mian, 2010; O'Cass and Voola, 2011; Smith, 2008; Smith and French, 2009; Speed et al., 2015). This simple approach allows us to 'make sense' of different types of political brands and 
serves to ground studies, followed by the adoption of a theoretical lens. It is encouraging to see that political marketing research continues to broaden its scope and consider different typologies of political brands beyond party leader, party and policy. For example, existing research has focused on the investigation of party leader brands (Jain and Ganesh 2019), parliamentarians (Armannsdottir, Carnell and Pich 2019), and candidates and legislators (Falkowski and Jablonska 2019; Marland and Wagner 2019). However, recently, we have witnessed work on political brand communities (Newman 2019), cryptocurrencies [policy brands] (Harvey and Branco-Illodo 2019) and political brand communications (Susila, Dean, Nerina and Agus 2019).

More specifically, Jain and Ganesh (2019) focused on the importance of credibility of party leader brand image in the context of India's Prime Minister Narendra Modi. Their work investigated used secondary research to investigate how social media marketing is often utilised to build a credible, authentic yet personal political brand image. Indeed, Jain and Ganesh (2019) argued that party leaders should periodically consider the strategy of crisis management along with the adopting a collaborative co-constructed multi-stakeholder approach to develop political brand image in the mind of voters. Furthermore, they maintain that in order to create a credible, consistent political brand image, practitioners and politicians should not only embrace a professional persona but also communicate humility, personal characteristics and relatable personality. Despite that Jain and Ganesh's (2019) study was grounded on secondary research, they conclude that future work should conduct longitudinal research on the credibility of political brand image in other contexts and adopt different methodological approaches.

The exploration of the personal characteristics of political brands is proving a popular topic area within political marketing-branding. For instance Armannsdottir, Carnell and Pich (2019) investigated the personal political brand identities created and developed by Icelandic Parliamentarians from a brand creator [politician] perspective. Armannsdottir et al. (2019) framed their exploration with the concept of personal branding - a strategy grounded within the impression management literature designed to allow individuals to actively manage a positive identity and communicate desired impressions (Johnson 2014). Indeed, Armannsdottir et al. (2019) argued that personal political brands need to project an authentic 
character and distinct identity, structured around tangible dimensions such as physical appearance, style, online and offline communication tools and actions, and also intangible dimensions such as lived experiences, skills, values and personality characteristics. The firsthand accounts captured by Armannsdottir et al. (2019) demonstrate insight into the personal brand identity building process and allowed them to develop a theoretical model entitled the Personal Political Brand Identity Appraisal Framework, which could be used to periodically audit current identity and develop desired personal political brands of politicians and other political actors.

Similarly, Marland and Wagner (2019) and Falkowski and Jablonska (2019) continued with the typology of candidates and legislators as political brands. Indeed, Marland and Wagner (2019) examined the link between personal political brands and party discipline. Furthermore, their qualitative study contextualised in the political party system of Canada highlighted that candidates are often characterised as brand ambassadors or brand champions of the corporate 'party' brand. Political brand ambassadors must adhere to party message and stick to the approved script in order to communicate a coherent position and for the brand to be deemed authentic. In addition, candidates can be considered a 'franchise' of the corporate party and will be disciplined and potentially expelled from the corporate party if they are not 'on message'. Corporate parties must strike a fine balance between party 'authority and individual authenticity' (Marland and Wagner 2019) in order to minimise tensions and misalignment. Therefore, discipline and maintaining the mantra of being 'on message' can stifle individuality and highlights the difficulty of developing personal political brands (Marland and Wagner 2019). Being 'on message' is only one aspect of the political brand management process. Indeed, successful political messages, campaigns and policies need to be made relevant, clearly communicated and 'framed' in order to capture and maintain the interests of voters (Falkowski and Jablonska 2019). Falkowski and Jablonska (2019) assessed the priming, framing and agenda setting by political parties as a means of developing persuasive messages and contributing to the management of candidate political brand image. Furthermore, Falkowski and Jablonska (2019) argued that framing messages, creating favourable associations and desired imagery is strategic in nature and part of an ongoing process of political brand management. Therefore, they suggested that successful candidate image can improve voting intention for the candidate [and party] as long as messages, policies 
and campaigns are made relevant and appealing to voters. Thus framing involves clearly communicating the implications of policy in action (Falkowski and Jablonska 2019). Finally, Falkowski and Jablonska (2019) continue to call for more research into the political brand management process and specifically call for more insight into the use of artificial intelligence [AI] in political marketing.

Nevertheless, understanding how political brands communicate and engage with voters continues to be a core area of research within political marketing. Likewise, Susila, Dean, Nerina and Agus (2019) examined this topic area in an under-researched context and interestingly from a young voter perspective. More specifically, Susila et al. (2019) explored how young voters understand symbolic communication created and expressed by politicians and government and assessed how it related to the acceptance and engagement with political brands. Indonesia was used to contextualise the study as it is 'both secular and the world's largest Muslim democracy' (Susila et al. 2019:2). Susila et al. (2019) revealed the important role of political communication in building trust and ensuring that political brands are considered believable and authentic. Indeed, they highlighted that trustworthy political brands can mobilise citizens and lead to participation in the electoral process by communicating an array of signals ranging from intangible, symbolic, value-laden cues and tangible elements such as appearance of candidates in terms of apparel and style. Just like the work of Armannsdottir et al. (2019) and Jain and Ganesh (2019), Susila et al. (2019) developed a systematic framework for academics, practitioners and politicians. Their framework can be used as a mechanism to generate a greater understanding of the cultural antecedents of trust in political brand communications (Susila et al. 2019). Furthermore, the systematic frameworks demonstrate the development of political marketing-branding discipline and raises the gauntlet for further academic research and highlights the practical implications of research in action (Armannsdottir et al. 2019; Jain and Ganesh 2019; Susila et al. 2019).

Nonetheless, returning to Susila et al. (2019), it reminds us that it is important that political brands in all shapes and sizes from parties, governments, politicians, policies, campaigns, movements or nationals/regions need to routinely understand how they communicate and position their brands as this will reveal if they are clearly differentiated from competitors and 
provide citizens rationale for identification. Indeed, Newman (2019) highlighted there is limited insight into how political brands utilise 'science' and 'science related issues' as a means of differentiation and creation of political brand communities within the political environment of the United States of America. Furthermore, Newman (2019) demonstrated that the emergence of different typologies of political brands such as political brand communities and their use of 'science' as a unique selling point reinforced the importance of a clear, coherent identity. The use of the 'science brand' fused as part of a politician's or party's' identity may strengthen the levels of trust in the mind of citizens as this will enhance the authority and credibility of political brands (Newman 2019). This in turn reminds political marketers that strong political brands are supported and created by a collaborative community or wide ecosystem of stakeholders.

The emergence of alternative and different typologies of political brands continues to highlight the numerous gaps that continue to exist within the academic literature. For example, Harvey and Branco-Illodo (2019) challenge the existing boundaries of political brands and reconceptualise a new style of political brand in the form of cryptocurrencies. Cryptocurrencies are digital currencies used by political, public and private groups and individuals as an online monetary community that utilise cryptography for robust security procedures and anti-counterfeiting in nature (Harvey and Branco-Illodo (2019). Looking back at the existing studies that tend to be grouped via the trinity of elements [party, leader and policy], is difficult to categorise cryptocurrencies as political brands in relation to the existing trinity conceptualisation. Harvey and Branco-Illodo (2019) argue that cryptocurrencies often referred to as 'privacy coins' provide the user with a degree of confidentiality and anonymity and questions the political motivations of this digital currency. Further, they highlight the growing interest yet limited understanding of cryptocurrencies and propose that they often position themselves as political brands pointing to alignment with political philosophies and ideologies. Therefore, Harvey and Branco-Illodo (2019) present a theoretical-conceptual paper not only raising the proposition that cryptocurrencies can be conceptualised as political brands but identify the ethical tensions present within the communities of people calling for the adoption of privacy coins. This paper raises an interesting point in that we should continually challenge the conceptualisation of political brands, be prepared to 
reconceptualise and accept that there are many typologies of political brands. This reveals many areas of future research.

\section{Political Branding - A Multifaceted Environment}

As we reflect on the recent articles published on political brands, it reminds us that political brands are complex, multifaceted and there continues to be many areas which remain underdeveloped and under-researched. On the one hand, it is important to adopt a critical perspective and revisit concepts, theories and frameworks that have already been applied to political marketing-branding to develop, build on and challenge in different settings and contexts. For example, concepts such as engagement, identity, image, reputation, equity and positioning. Alternatively, there are many concepts, theories and frameworks that have yet to be extended to political marketing-branding such as brand communities, value co-creation, brand architecture and event branding to name but a few and deserve a first visit. This demonstrates numerous opportunities for political branding research particularly as traditional political systems face turbulent times and constitutional crises and new political systems emerge.

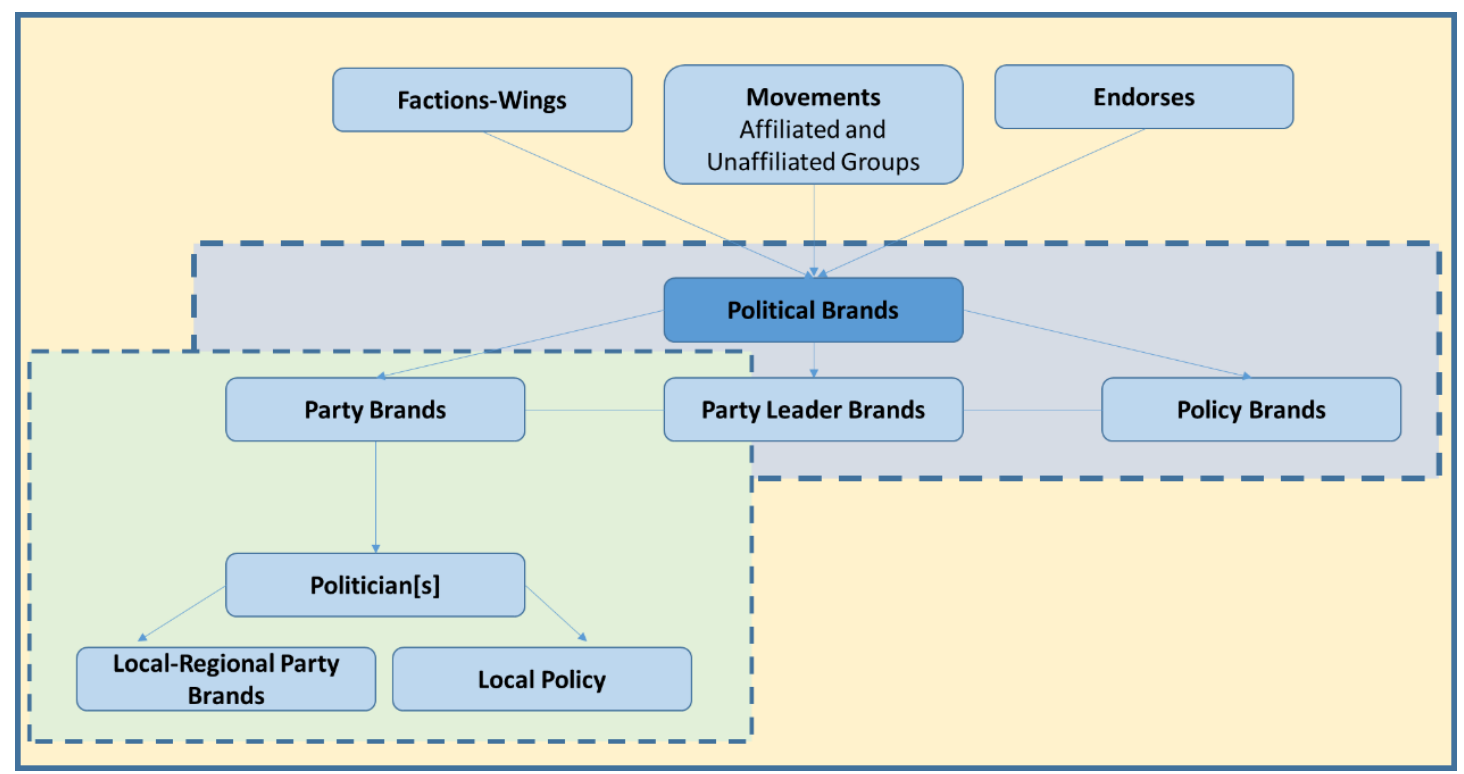

(Figure 2: The Political Branding Environment)

As we have identified different typologies and the complex nature of political brands, it is important to start to map out the political branding environment as political brands go beyond the party, leader and policy. Building on the trinity of elements (Bulter et al. 2011; 
Davies and Mian 2010; O'Cass and Voola 2011; Smith 2008; Smith and French 2009), we put forward the start of an updated environment of elements [figure 2]. The environment of elements highlight the overlapping yet distinct nature of political brands. For example, party political brands can also be divided into a sub-trinity. Politicians or Members of Parliament will be the leader of their local party/constituency, which will include local supporters, activities and party members. The politician or Member of Parliament could also have localised policies, which could be distinct from party policy. This represents a sub-political brand, which again needs a degree of alignment with the party political brand. Likewise, there are many different types of sub-political brands which can be affiliated [and unaffiliated] or factions within party political brands such as political groups, movements, endorses and can be seen as political brands in their own right. Therefore, this suggests that there are multiple relationships and numerous interconnected political brands, which represents an intricate environment or ecosystem. This represents the starting point for further research in political brands.

\section{Conclusion and Future Research}

This article not only highlights the diversity of political branding research often in different contexts and settings but also reveals that there are many under-researched and underdeveloped areas of study. Indeed, despite significant progress in this area including in this special issue, there remains many under-developed areas. Ideology [values], campaigns outside election periods, political movements, comparative and longitudinal studies, ecosystems, nationals/destinations, events, sub-groups/wings, movements, political groups, endorses and populism. In addition, further research should adopt a multidiscipline approach and consider using theoretical lens [concepts, theories and frameworks] from other disciplines across marketing, psychology and social sciences. Therefore, the special issue of the Journal of Political Marketing suggests several considerations for future research that will demonstrate theoretical and managerial relevance and impact including:

- Alternative political brands - [beyond corporate and local-individual]

- Sub-political brands

- Political collaborative consumption

- Comparative research

- Longitudinal research 
- Contemporary issues

- Additional frameworks

- Multi-discipline approach

- Ecosystems

- Irregular settings and contexts - [new democracies, under-researched jurisdictions and island communities for example]

- New political brands - [such as Bitcoin, Crypto-Currencies, Foodbanks, political movements, trade unions etc]

- Online political brand communities [virtual political market places]

- Radical movements-grassroots groups

- The rise of alternative economies

- Pop-up political brands - [Vote Leave and Vote Remain - UK Referendum for example]

- Long-term engagement and participation 


\section{References}

Ahmed, M.A. Lodhi, A.S. and Ahmad, Z. (2015), 'Political Brand Equity Model: The Integration of Political Brands in Voter Choice', Journal of Political Marketing, DOI: 10.1080/15377857.2015.1022629

Armannsdottir, G. Carnell, S. and Pich, C. (2019), 'Exploring Personal Politic Brands of Iceland's Parliamentarians', Journal of Political Marketing, 19(1,2).

Baines, P. Crawford, I. O'Shaughnessy, N. Worcester, R. and Mortimore, R. (2014), 'Positioning in political marketing: How semiotic analysis adds value to traditional survey approaches', Journal of Marketing Management, 30(1-2), 172-200.

Billard, T. J. (2018), 'Citizen typography and political brands in the 2016 US presidential election campaign', Marketing Theory, DOI: 10.1177/1470593118763982

Falkowski, A. and Jabłońska, M. (2019), 'Moderators and Mediators of Framing Effects in Political Marketing. Implications for political Brand Management', Journal of Political Marketing, 19(1,2).

Guzman, F. and Sierra, V. (2009), 'A political candidate's brand image scale: Are political candidates brands', Journal of Brand Management 17(3), 207-217.

Harris, P. and Lock, A. (2010), 'Mind the gap: the rise of political marketing and a perspective on its future agenda', European Journal of Marketing 44(3/4), 297-307.

Harvey, J. and Branco-lllodo, I. (2019), 'Why Cryptocurrencies want privacy: A Review of Political Motivations and Branding Expressed in 'Privacy Coin' Whitepapers', Journal of Political Marketing, 19(1,2).

Husted, E. Fredriksson, M. Moufahim, M. and Gronbaek Pors, J. (2018), 'Political parties: Exploring the inner life of party organisations', Theory and Politics in Organisation, ISSN 1473-2866, 1-7

Jain, V. and Ganesh, B. E. (2019), 'Understanding the magic of credibility for political leaders: A case of India and Narendra Modi', Journal of Political Marketing, 19(1,2).

Johnson, K. (2014), 'The importance of personal branding in social media: educating students to create and manage their personal brand', International Journal of Education and Social Sciences, 4(1), 1-8

Lock, A. and Harris, P. (1996), 'Political Marketing - vive la difference!' European Journal of Marketing, 30(10-11), 21-31.

Marland, A. (2019), 'How Party Discipline and Branding Turn Election Candidates and Legislators into Brand Ambassadors: Canada', Journal of Political Marketing, 19(1,2).

Marland, A. (2016). Brand Command: Canadian Politics and Democracy in the Age of Message Control. Vancouver: UBC Press.

Marland, A. and Flanagan, T. (2014), 'Brand New Party: Political Branding and the Conservative Party of Canada', Canadian Journal of Political science, 46(4), 951-972.

Meyerrose, A. M. (2017), 'It is all about value: How domestic party brands influence voting patterns in the European Parliament', Governance: An International Journal of Policy, Administration and Institutions, 24(2) 1-18. 
Nai, A. and Martinez, F. (2019), 'The personality of populists: provocateurs, charismatic leaders, or drunken dinner guests?' West European Politics, DOI: 10.1080/01402382.2019.1599570

Needham, C. and Smith, G. (2015), 'Introduction: Political Branding', Journal of Political Marketing, DOI:10.1080/15377857.2014.990828

Newman, T. (2019), 'The Emergence of Science as a Political Brand: USA', Journal of Political Marketing, 19(1,2).

Newman, B.I. and Newman, T.P. (2018). Brand. Dubuque, IA: Kendall Hunt Publishing Co.

Nielsen, S.W. (2016), 'Measuring Political Brands: An Art and a Science of Mapping the Mind', Journal of Political Marketing, 15(1), 70-95.

Nielsen, S. W. and Larsen, V. M. (2014), 'Party Brands and Voting', Journal of Electoral Studies 33(2014), 153-165.

Peng, N., and Hackley, C. (2009), 'Are Voters, Consumers? A qualitative exploration of the voter-consumer analogy in political marketing', Qualitative Market Research: An International Journal 12(2), 171-186.

Phipps, M. Brace-Govan, J. and Jevons, C. (2010), 'The duality of political brand equity', European Journal of Marketing, 44(3/4), 496-514.

Pich C. Armannsdottir G. Spry L. (2018), 'Investigating political brand reputation with qualitative projective techniques from the perspective of young adults', International Journal of Market Research, Online January $12^{\text {th }} 2018$, https://doi.org/10.1177/1470785317750817

Scammell, M, (2015), 'Politics and Image: The Conceptual Value of Branding', Journal of Political Marketing, 14(1-2), 7-18.

Simons, G. (2016), 'Stability and Change in Putin's Political Image during the 2000 and 2012 Presidential Elections: Putin 1.0 and Putin 2.0'. Journal of Political Marketing, DOI: 10.1080/15377857.2016.1151114

Smith, G. (2009), 'Conceptualising and Testing Brand Personality in British Politics', Journal of Political Marketing, 8(3), 209-232.

Speed, R. Butler, P. and Collins, N. (2015), 'Human branding in political marketing: Applying contemporary branding thoughts to political parties and their leaders', Journal of Political Marketing, 14(1-2), 129-151.

Susila, I. Dean, D. Nerina Raja Yusof, R. and Setyawan, A. A. (2019), 'Symbolic Political Communications and Trust: A young voters' perspective of the Indonesian presidential election', Journal of Political Marketing, 19(1,2).

\section{AUTHOR NOTES}

Christopher Pich is a senior lecturer in Marketing at Nottingham Business School, Nottingham Trent University, United Kingdom. He completed his PhD research in 2012 at the University of Hull, UK, on political brand identity and image of the UK Conservative Party from an internal and external perspective. Christopher is an active researcher currently focusing on different types of political brands including new-established parties, leaders, nations, politicians and campaigns in different contexts. Contexts range from national-local levels, traditional partysystems and non-party-systems to settings such as the United Kingdom, Italy, India, Iceland and the Channel Island of Guernsey. In addition, Christopher is interested in the application and analysis of qualitative projective techniques. He has published in a range of ABS journals 
such as the European Journal of Marketing, Journal of Business Research, Journal of Marketing Management, Journal of Strategic Marketing, International Journal of Market Research, and Qualitative Market Research: An International Journal, Journal of Marketing Communications and Journal of Politics and Policy. Since January 2016, Christopher has been the Managing Editor for Europe for the Journal of Political Marketing. Finally, he continues to frame political marketing research through different conceptualisations of branding such as brand identity, brand image, brand reputation, co-creation, brand equity, personal branding and co-branding within politics.

Bruce I. Newman is Professor of Marketing and Wicklander Fellow in Business Ethics at DePaul University, U.S. He is the founding Editor-in-Chief of the Journal of Political Marketing and has published numerous books and articles on the subjects of political marketing; consumer choice modelling; consumer behavior and voter behavior. 